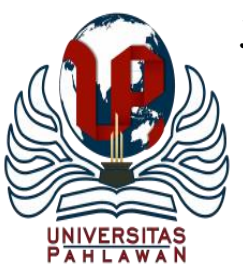

Jurnal Basicedu Volume 4 Nomor 4 Tahun 2020 Halm. 899-906

JURNAL BASICEDU

Research \& Learning in Elementary Education

https://jbasic.org/index.php/basicedu/index

\title{
Pengembangan Bahan Ajar Menggunakan Literasi Musik di Kelas IV Sekolah Dasar
}

\author{
Ardipal $^{1}$, Ayu Niza Machfauzia ${ }^{2}$, Ahmad Zikri ${ }^{3}$ \\ Dosen Pendidikan Seni, FBS Universitas Negeri Padang ${ }^{1}$ \\ Dosen Pendidikan Seni, FBS Universitas Negeri Yogyakarta ${ }^{2}$ \\ Mahasiswa Pendidikan Dasar. FIP Universitas Negeri Padang ${ }^{3}$ \\ E-mail: ardipalarly@gmail.com ${ }^{1}, \underline{\text { ayu@ uny.ac.id }}$, zikria79@yahoo.com ${ }^{3}$
}

\begin{abstract}
Abstrak
Penelitian ini bertujuan untuk menghasilkan literasi musik untuk siswa kelas IV yang valid, praktis, dan efektif. Penelitian ini menggunakan penelitian pengembangan berdasarkan model 4D (Define, Design, Develop dan Disseminate). Kevalidan dilihat dari segi isi, bahasa, penyajian, kegrafikan dan RPP, keseluruhan 3,78 dengan kategori sangat valid. Pratikalitas bahan ajar dilihat dari respon pendidik dengan rata-rata $90 \%$ respon peserta didik 90\%. Dapat disimpulkan bahwa bahan ajar literasi musik yang dikembangkan layak digunakan di kelas IV SD.
\end{abstract}

Kata kunci: bahan ajar, pembelajaran tematik, literasi musik

\section{Abstract}

This study aims to produce music literacy for class IV students that is valid, practical, and effective. This study uses development research based on the 4D model (Define, Design, Develop and Disseminate). Validity is seen in terms of content, language, presentation, graphic and lesson plan, overall 3.78 with a very valid category. The practicality of teaching materials is seen from the responses of educators with an average of $90 \%$ of students' responses by $90 \%$. It can be concluded that the developed music literacy teaching material is suitable for use in grade IV elementary school.

Keywords: teaching material, thematic learning, literacy music

Copyright (c) 2020 Ardipal, Ayu Niza Machfauzia, Ahmad Zikri

$\triangle$ Corresponding author :

Address : Air Tawar Padang

Email : Ardipalarly@gmail.com

ISSN 2580-3735 (Media Cetak)

Phone : 089531307164

ISSN 2580-1147 (Media Online)

DOI : https://doi.org/10.31004/basicedu.v4i4.375 


\section{PENDAHULUAN}

Perkembangan era revolusi mental erat kaitannya dengan perkembangan dengan literasi. Khususnya dalam kegiatan menerapkan literasi musik di Sekolah Dasar (Suwardana, 2018). Salah satu cara menerapkan literasi musik di SD tersebut adalah dengan bahan ajar literasi musik. Bahan ajar literasi musik merupakan cara yang digunakan guru dalam mengajarkan pembelajaran musik yang menyenangkan, komunikatif, dan menarik (Gustine, 2018).

Sekolah Dasar memiliki peran dalam pelaksanaan program PPK. Hal ini menunjukkan bahwa Sekolah Dasar sudah memenuhi kualifikasi dalam melaksanakan berkarakter (Suyanto, 2012). Dengan adanya amanah yang diberikan oleh Menteri Pendidikan dan Kebudayaan tersebut, menjadikan peserta didik memiliki minat dan tanggung jawab penuh untuk menjadikan sekolah berkarakter. Salah satunya dengan menggiatkan kegiatan literasi musik yang digalakkan setiap hari (Permendikbud, 2013).

Bahan ajar yang digunakan pada proses pembelajaran sesuai dengan kurikulum yang berlaku. Bahan ajar penting dalam proses pembelajaran. Pentingnya bahan ajar antara lain: (1) merupakan alat bantu guru dalam pembelajaran (Vivi, Fitria, Miaz, \& Ahmad, 2020), (2) bahan ajar dapat menarik perhatian siswa dalam pembeajaran karena memiliki desain dan gambar yang menarik, (3) bahan ajar juga cara inovatif guru dalam mengembangkan pembelajaran dengan berbagai karakteristik siswa, (4) bahan ajar penting sebagai referensi guru dalam memperbaiki pembelajaran yang selanjutnya (Hernawan,
Permasih, \& Dewi, 2008). Akan tetapi, bahan ajar yang di gunakan belum menggambarkan pentingnya bahan ajar itu digunakan.

Mata pelajaran yang perlu diperhatikan dalam pengembangan bahan ajar salah satunya adalah SBdP. Pembelajaran SBdP memuat berbagai kerampilan seni dan budaya, yaitu musik, tari, ukir (Ardipal, 2018). Namun, musik yang merupakan salah satu keterampilan seni, sangat penting di samping tiga keterampilan lainnya. Hal ini didasarkan karena musik merupakan hal-hal telah kita nikmati sehari-hari karena segala kegiatan kita pasti tidak jauh dari musik seperti acara pernikahan menggunakan musik, pembukaan acara menggunakan musik, bahkan kegiatan keagamaan seperti nasyid (Joseph, 2017; Maladerita, Ardipal, Desyandri, \& Zikri, 2019). Walaupun demikian, bukanlah suatu pekerjaan yang mudah untuk dilakukan dan perlu bimbingan melalui proses pembelajaran yang tepat. Agar pembelajaran menjadi tepat maka dibutuhkan bahan ajar pembelajaran seni.

Bahan ajar pembelajaran seni lebih khusus seni musik, di SD pada umumnya masih menggunakan pendekatan subjectcentered curriculum. Tidak jelas, kompetensi apa yang harus dicapai oleh siswa setelah mereka mengikuti serentetan pelajaran tersebut (Desyandri \& Vernanda, 2017). Tidak jelas pula artikulasi isi mata pelajaran antara jenis dan jenjang pendidikan, sehingga sering dijumpai ucapan yang terlontar dari pendidik yang penting kegiatan pembelajaran seni musik ada, sehingga terjadi pengulanganpengulangan pelajaran sebelumnya. Link and 
match lemah, sehingga terjadi pemborosan (Taufina \& Chandra, 2017). Karena kurangnya pemahaman para pendidik terhadap seni musik lebih khusus lagi tentang pendidikan seni musik, menyebabkan pelaksanaan pembelajaran kehilangan kelenturannya untuk disesuaikan dengan keadaan lingkungan setempat dan kebutuhan batin siswa pada pendidikan seni musik (Simamora, Siagian, \& Sitompul, 2018).

Berdasarkan pengamatan dan wawancara di SDN 13 Batang Gasan selama 2 minggu, ditemukan beberapa kebutuhan dan permasalahan utama. Pertama masih banyaknya peserta didik menyanyikan lagu seperti membaca teks. Hal ini terbukti dengan banyaknya siswa menyanyi dengan nada datar pada pembelajaran di kelas. Kedua sekolah seharusnya memiliki bahan ajar literasi musik sendiri, namun nyatanya di SDN 13 Batang Gasan belum memiliki bahan ajar literasi musik. Ketiga, sekolah sebagai pelaksana Penguatan Pendidikan Karakter (PPK) menjadikan kegiatan berbasis literasi (Nur, 2018). Namun kegiatan literasi belum terlihat dilaksanakan di sekolah tersebut. Keempat, masih banyaknya lagu yang tidak sesuai dengan usia peserta didik yang mengakibatkan banyaknya perilaku yang tidak mendidik (http://news.detik.com). Padahal sebelum adanya televisi dan gadget siswa sering menyanyikan lagu seusianya seperti lagu lihat kebunku.

Berdasarkan permasalahan tersebut, perlu adanya upaya dalam meningkatkan literasi musik peserta didik. Salah satunya dengan menggunakan bahan ajar literasi musik. Dengan tersedianya bahan ajar literasi musik, diharapkan peserta didik dapat menyalurkan minat terhadap musik, karena ia merasa bahwa pembelajaran musik sangat penting dalam perkembangan emosinya. Hal ini sesuai dengan Tugas Pokok Guru dalam Permendikbud Nomor 15 Tahun 2018 salah satunya terdapat pada tugas pokok keempat yaitu membimbing dan melatih peserta didik. Oleh sebab itu, penulis tertarik untuk merancang penelitian dengan judul "Pengembangan Bahan Ajar Menggunakan Literasi Musik di kelas IV Siswa SD”.

\section{METODE}

Bahan ajar yang dikembangkan menggunakan metode penelitian pengembangan yang sering disebut Research and Development (R\&D) (Setyosari, 2016; Sugiyono, 2013). Sesuai dengan permasalahan yang diteliti dan berpedoman pada tujuan penelitian yaitu menghasilkan bahan ajar yang valid.

Penelitian dan pengembangan merupakan proses/metode yang digunakan untuk memvalidasi dan mengembangkan produk (Latief, 2009). Penelitian pengembangan adalah suatu penelitian yang digunakan untuk mengembangkan, memvalidasi, menguji keefektifan produk yang digunakan dalam pendidikan. Produk yang dihasilkan dapat berupa bahan ajar, materi belajar, media, soal, dan sistem pengelolaan dalam proses pembelajaran.

\section{Tahap Pendefinisian (Define)}

Pelaksanaan pertama adalah tahap define. Tahap pendefinisian bertujuan untuk menetapkan dan mendefinisikan syarat-syarat 
yang dibutuhkan dalam pengembangan bahan ajar. Tahap ini dilakukan dengan menganalisis tujuan dalam batasan materi pelajaran yang dikembangkan. Terdapat tiga langkah yang dilakukan dalam tahap pendefinisian, yaitu:

\section{a. Analisis Kebutuhan}

Analisis kurikulum yang dilakukan dengan menganalisis KI, KD, dan indikator pencapaian kompetensi materi yang terdapat pada buku kurikulum 2013 revisi 2017. Dari indikator dirumuskan tujuan pembelajaran yang hendak dicapai oleh siswa. Beberapa hal yang perlu diperhatikan pada analisis kurikulum ini adalah analisis materi pada tema 3 kelas IV semester I.

\section{b. Analisis Peserta Didik}

Analisis kebutuhan dilakukan dengan menganalisi buku guru dan buku siswa. Analisis buku guru dilakukan untuk menelaah keterkaitan anatara indikator, tujuan pembelajaran yang hendak dicapai pada kelas IV semester I di dalam tema 3. Analisis ini dilihat permasalahan yang berkaitan dalam pengembangan bahan ajar literasi musik. Analisis buku siswa dilakukan dengan menelaah materi beserta gambar yang terdapat dalam buku siswa. Subjek penelitian adalah buku siswa kelas IV semester I pada tema 3. Hasil analisis ini dijadikan gambaran untuk mengembangkan bahan ajar literasi musik.

\section{Tahap Perancangan (Desaign)}

Tahap perancangan (design) bertujuan untuk merancangan bahan ajar. Bahan ajar dirancang sedemikian rupa sehingga siswa dapat belajar sesuai dengan kemampuan belajarnya masingmasing. Perancangan bahan ajar dilakukan dengan memilih format yang sesuai dengan format penelitian bahan ajar yang baik dan benar dengan memperhatikan kesesuaian materi dan kurikulum. Pengembangan bahan ajar disusun sesuai tuntutan KI, KD, indikator dan tujuan pembelajaran yang mengaju pada komponen yang terdapat pada bahan ajar. Pengembangan bahan ajar ini juga memperhatikan cara penyajian materi pembelajaran tematik terpadu menggunakan literasi musik.

\section{Tahap Pengembangan (Develop)}

Tahap pengembangan (develop) bertujuan untuk menghasilkan bahan ajar yang valid, praktis, dan efektif. Tahap pengembangan meliputi:

1. Validitas isi (content validity), yaitu apakah bahan ajar yang dirancang sesuai dengan literasi musik.

2. Validitas konstruk (construct validity), yaitu kesesuaian komponen-komponen pengembangan yang sudah ditetapkan.

\section{a. Praktikalitas Bahan Ajar}

Bahan ajar yang digunakan merupakan bahan ajar yang telah divalidasi oleh validator. Uji praktikalitas bahan ajar dilakukan menggunakan angket dan lembar observasi. Observasi dilakukan oleh dua orang pengamat, yaitu guru dan peneliti sendiri. Observer mengamati keterpakaian bahan ajar dalam proses pembelajaran dan mengisi instrumen observasi yang telah disiapkan. observer mengisi angket 
keterpakaian bahan literasi musik. Hasil angket ini dijadikan sebagai dasar untuk melakukan perbaikan terhadap bahan ajar yang dikembangkan. Aspek keterlaksanaan pembelajaran dilihat dari hasil pengisian lembar keterlaksanaan RPP oleh dua orang observer.

\section{b. Efektivitas Bahan Ajar Pembelajaran}

Efektivitas dilakukan untuk mengevaluasi bahan ajar telah efektif atau tidaknya. Hal yang dilakukan dengan melihat aktivitas dari pembelajaran.

\section{Tahap Penyebaran (disseminate)}

Tahap ini merupakan tahap penggunaan bahan ajar yang telah dikembangkan pada subjek lain, misalnya di kelas lain, atau sekolah lain. Tujuannya adalah untuk menguji efektivitas penggunaan bahan ajar tersebut pada subjek yang berbeda. Bahan ajar yang dikatakan efektif jika dapat memberikan hasil yang baik terhadap hasil belajar siswa. Peneliti melakukan penyebaran bahan ajar literasi musik dalam skala terbatas yaitu di kelas IV SDN 13 Batang Gasan Kab. Padang Pariaman.

\section{HASIL DAN PEMBAHASAN}

\section{Hasil Validasi}

\section{a. Validasi Isi}

Validasi ahli isi/materi diperlukan sebagai suatu bentuk evaluasi terhadap isi/materi serta penyajian produk yang telah dikembangkan. Data yang diperoleh berupa data kuantitatif dan kualitatif melalui angket yang diberikan peneliti kepada ahli. Peneliti memberikan angket validasi isi/ materi, dan produk yang dikembangkan. Berdasarkan perhitungan data angket yang diperoleh dari validasi diperoleh sebesar 3,5 dengan kategori sangat valid.

Tabel 1. Hasil Validasi Isi

\begin{tabular}{clc}
\hline No & \multicolumn{1}{c}{ Aspek yang Dinilai } & Nilai Validasi \\
\hline 1 & Judul dan Kesesuaian & 4 \\
& Materi & \\
2 & Dimensi Spiritual (KI 1) & 4 \\
3 & Dimensi Sosial (KI 2) & 3 \\
4 & Dimensi Pengetahuan (KI & 3 \\
& 3) & 4 \\
5 & Dimensi Keterampilan & 3 \\
6 & $\begin{array}{l}\text { Kesesuain Latihan dengan } \\
\text { Indikator } \\
\quad \text { Rata-rata }\end{array}$ \\
$\quad$ & $\mathbf{3 , 5}$ \\
\hline
\end{tabular}

b. Validasi Bahasa

Validasi bahasa diperlukan sebagai evaluasi terhadap bahasa yang digunakan dalam bahan ajar yang sudah dikembangkan. Penggunaan bahasa yang efektif dan komunikatif sangatlah penting dalam sebuah bahan ajar membaca permulaan. Validitas bahasa diberikan kepada ahli berupa angket yang menunjukkan perolehan 3,6 dengan kategori sangat valid.

Tabel 2. Hasil Validasi Bahasa

\begin{tabular}{clc}
\hline No & \multicolumn{1}{c}{ Aspek yang Dinilai } & Nilai Validasi \\
\hline 1 & Tata Bahasa & 4 \\
2 & EYD & 3 \\
3 & Kesesuaian bahasa dengan & 4 \\
& Usia & 4 \\
4 & Penggunaan Istilah & 3 \\
5 & $\begin{array}{l}\text { Penggunaan bahasa tidak } \\
\text { ambigu }\end{array}$ & $\mathbf{3 , 6}$ \\
$\quad$ Rata-rata &
\end{tabular}




\section{c. Validasi Aspek Penyajian}

Validasi penyajian diperlukan sebagai evaluasi terhadap tampilan bahan ajar membaxa permulaan. Data yang diperoleh berupa data kuantitatif dan kualitatif melalui angket yang diberikan peneliti kepada ahli desain pembelajaran. Berdasarkan perhitungan data angket yang diperoleh dari validasi ahli desain menunjukkan perolehan sebesar 3,57 dengan kategori sangat valid.

Tabel 3. Hasil Validasi Bahan Penyajian

\begin{tabular}{clc}
\hline No & Aspek yang Dinilai & Nilai Validasi \\
\hline $\mathbf{1}$ & Ukuran Buku & 4 \\
$\mathbf{2}$ & Desain Cover Buku & 4 \\
$\mathbf{3}$ & Tipogravi Cover Buku & 3 \\
$\mathbf{4}$ & Ilustrasi Cover Buku & 4 \\
$\mathbf{5}$ & Huruf yang komunikatif & 4 \\
$\mathbf{6}$ & Tata Letak Isi Buku & 3 \\
$\mathbf{7}$ & Ilustrasi Isi Buku & 3 \\
& Rata-rata & $\mathbf{3 , 5 7}$ \\
\hline
\end{tabular}

Berdasarkan hasil validasi ahli yang dilakukan peneliti maka bahan ajar dikatakan sangat praktis dengan nilai 3,57. Hasil validasi bahan ajar dapat dilihat pada tabel 4 :

Tabel 4. Hasil Validasi Bahan Ajar

\begin{tabular}{clc}
\hline No & Aspek yang Dinilai & Nilai Validasi \\
\hline $\mathbf{1}$ & Kelayakan isi & 3,5 \\
$\mathbf{2}$ & Kebahasaan & 3,6 \\
$\mathbf{3}$ & Penyajian & 3,57 \\
& Rata-rata & $\mathbf{3 , 5 5}$ \\
\hline
\end{tabular}

\section{Praktikalitas}

Salah satu tujuan yang hendak dicapai dari penelitian ini yaitu memperoleh bahan ajar literasi musik di Kelas IV SD yang praktis dan efektif. Setelah dinyatakan praktis dan efektif, kemudian dilakukan dalam kelompok kecil one to one kemudian dilanjutkan dengan small group kemudian dilakukan uji efektifitas bahan ajar.

Hasil observasi saat uji coba di lapangan sesuai dengan perencanaan yang telah di buat dengan presentase $86 \%$ dengan kategori sangat praktis. Hasil praktikalitas dapat dilihat pada tabel 5:

Tabel 5. Hasil Praktikalitas Bahan Ajar

\begin{tabular}{clc}
\hline No & Aspek yang Dinilai & Nilai Validasi \\
\hline $\mathbf{1}$ & Kreatif & 4 \\
$\mathbf{2}$ & Efesien & 3 \\
$\mathbf{3}$ & Interaktif & 3 \\
$\mathbf{4}$ & Menarik & 4 \\
$\mathbf{5}$ & Efesien & 3 \\
& $\quad$ Rata-rata & $\mathbf{1 7}$ \\
& & $\mathbf{x 1 0 0} \% \mathbf{= 8 5 \%}$ \\
\hline
\end{tabular}

\section{Efektivitas Bahan Ajar}

Bahan ajar dikatakan efektif apabila memberikan efek atau pengaruh baik terhadap pencapaian tujuan bahan ajar yang dikembangkan. Efektivitas peserta didik dilihat dari hasil belajar peserta didik dalam proses pembelajaran. Hasil analisis data terhadap aktivitas peserta didik ketika proses pembelajaran dengan memperolah hasil $88 \%$.

\section{KESIMPULAN}

Berdasarkan pengembangan, uji coba, dan penyebaran yang dilakukan peneliti dapat menyimpulkan beberapa hal, sebagai berikut:

1. Bahan ajar menggunakan literasi musik. Hasil validasi yang dilakukan menunjukkan bahwa bahan ajar yang dikembangkan 
berada pada kategori sangat valid. Hal ini terlihat dari perolehan hasil validasi yang dilakukan validator ahli yaitu 3,78 dengan kategori sangat valid.

2. Bahan ajar menggunakan literasi musik yang dihasilkan pada penelitian pengembangan ini telah dapat dinyatakan sangat praktis dari hasil analisis respon guru yaitu dengan rata-rata 90\%, dan aspek respon siswa dengan rata-rata $90 \%$.

3. Bahan ajar menggunakan literasi yang dihasilkan pada penelitian pengembangan ini telah dinyatakan efektif dilihat dari hasil aktivitas dan hasil belajar. Pada aspek sikap saat uji coba aspek pengetahuan saat uji coba diperoleh nilai presentase ketuntasan $90 \%$.

\section{SARAN}

Berdasarkan penelitian yang telah dilakukan, maka peneliti menyarankan hal-hal sebagai berikut:

1. Bagi peneliti, bahan ajar yang dikembangkan agar menjadi acuan dalam mengembangkan bahan ajar yang lain terutama yang berkaitan dengan pembelajaran tematik terpadu.

2. Bagi pendidik, agar dapat menggunakan bahan ajar yang telah dikembangkan secara valid dalam pembelajaran.

3. Bagi peneliti lain, agar dapat mengembangkan bahan ajar tematik terpadu menggunakan literasi musik.

4. Bagi pemerintah khususnya Dinas Pendidikan Kota Padang agar dapat mengadakan pelatihan bagi guru agar dapat mengembangkan bahan ajar yang sesuai dengan lingkungan siswa dan yang mampu mengembangkan keterampilan bertanya siswa.

\section{DAFTAR PUSTAKA}

Ardipal. (2018). Kurikulum Pendidikan Seni Budaya yang Ideal bagi Peserta Didik di Masa Depan. Komposisi: Jurnal Pendidikan Bahasa, Sastra, Dan Seni, 11(1). https://doi.org/10.24036/komposisi.v11i1. 69

Desyandri, \& Vernanda, D. (2017). Pengembangan Bahan Ajar Tematik Terpadu di Kelas V Sekolah Dasar Menggunakan Identifikasi Masalah. Seminar Nasional HDPGSDI Wilayah 4, 163-174.

Gustine, G. G. (2018). A Survey on Critical Literasi as a Pedagogical Approach. Indonesian Journal of Applied Linguistics, 7(3), 531-537.

Hernawan, A. H., Permasih, \& Dewi, L. (2008). Panduan Pengembangan Bahan Ajar. Depdiknas Jakarta.

Joseph, W. (2017). Pendidikan Kesenian di Sekolah Sub Materi Musik. Harmonia Jurnal Pengetahuan Dan Pemikiran Seni, 13(1), 302.

Latief, M. A. (2009). Penelitian Pengembangan. Universitas Stuttgart.

Maladerita, W., Ardipal, Desyandri, \& Zikri, A. (2019). Pengembangan Bahan Ajar Seni Pada Pembelajaran Tematik dengan Strategi Lesson Study di Sekolah Dasar. Jurnal Basicedu. https://doi.org/https://doi.org/10.31004/bas icedu.v3i3.205

Nur, L. (2018). The Implementation Of The Strengthening Character Education In Sdn 09 Mataram City, Nusa Tenggara Barat. Jurnal Pendidikan Karakter, 8(1), 17-28.

Permendikbud. (2013). Sistem Pendidikan 

Niza Machfauzia, Ahmad Zikrii

DOI:_https://doi.org/10.31004/basicedu.v4i4.375

Nasional. Permendikbud No. 20 Tahun 2013.

https://doi.org/10.16309/j.cnki.issn.10071776.2003.03.004

Setyosari, P. (2016). Metode Penelitian Pendidikan \& Pengembangan. In Metode Penelitian Pendidikan \& Pengembangan.

Simamora, D., Siagian, S., \& Sitompul, H. (2018). Pengaruh Multimedia Pembelajaran dan Kecerdasan Musikal Terhadap Hasil Belajar Piano Mahasiswa Jurusan Pendidikan Seni Musik. Jurnal TIK Dalam Pendidikan, 5(1), 87-99.

Sugiyono. (2013). Metode Penelitian Pendidikan Pendekatan Kuantitaif, Kualitatif, dan R\&D. Metode Penelitian Pendidikan Pendekatan Kuantitaif, Kualitatif, Dan $R \& D$. https://doi.org/10.1007/s13398-0140173-7.2

Suwardana, H. (2018). Revolusi Industri 4. 0 Berbasis Revolusi Mental. JATI UNIK: Jurnal Ilmiah Teknik Dan Manajemen Industri.

https://doi.org/10.30737/jatiunik.v1i2.117

Suyanto, S. (2012). Pendidikan Karakter untuk Anak Usia Dini. Pendidikan Karakter Untuk Anak Usia Dini.

Taufina, \& Chandra. (2017). Developing The Big Questions And Bookmark Organizers (Bqbo) Strategy-Based Literacy Reading Learning Materials In The 4th Grade Of Elementary School. In Social Science, Education and Humanities Research (Vol. 118, pp. 857-864). https://doi.org/10.2991/icset-17.2017.139

Vivi, L., Fitria, Y., Miaz, Y., \& Ahmad, Z. (2020). Pembelajaran IPA Dengan Strategi Pembelajaran Inkuiri Untuk Meningkatkan Keterampilan Proses Sains Dan Motivasi Belajar Siswa di Sekolah Dasar. Jurnal Basicedu. 